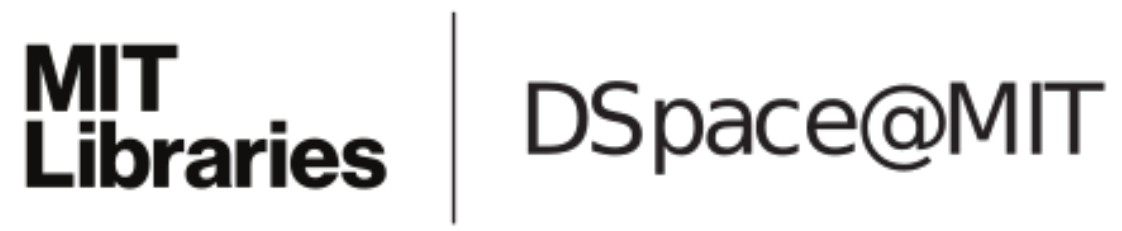

MIT Open Access Articles

Liposomes for HIV prophylaxis

The MIT Faculty has made this article openly available. Please share how this access benefits you. Your story matters.

Citation: Malavia, N. K., et al. "Liposomes for Hiv Prophylaxis." Biomaterials (2011).

As Published: 10.1016/j.biomaterials.2011.07.068

Publisher: Elsevier BV

Persistent URL: https://hdl.handle.net/1721.1/134469

Version: Author's final manuscript: final author's manuscript post peer review, without publisher's formatting or copy editing

Terms of use: Creative Commons Attribution-NonCommercial-NoDerivs License 
Biomaterials. 2011 November ; 32(33): 8663-8668. doi:10.1016/j.biomaterials.2011.07.068.

\title{
Liposomes for HIV prophylaxis
}

\author{
Nikita Malavia ${ }^{a, b}$, David Zurakowski ${ }^{\mathrm{c}}$, Avi Schroeder ${ }^{\mathrm{b}}$, Amy Princiotto ${ }^{\mathrm{d}, \mathrm{e}}$, Anna Ray Laury ${ }^{\dagger}$, \\ Hila Epstein-Barash ${ }^{\mathrm{a}, \mathrm{b}}$, Joseph Sodroski ${ }^{\mathrm{d}, \mathrm{e}}$, Robert Langer ${ }^{\mathrm{b}}$, Navid Madani ${ }^{\mathrm{d}, \mathrm{e}}$, and Daniel S. \\ Kohane ${ }^{a,{ }^{*}}$ \\ aLaboratory for Biomaterials and Drug Delivery, Department of Anesthesiology, Division of Critical \\ Care Medicine, Childrens Hospital Boston, Harvard Medical School, 300 Longwood Avenue, \\ Boston 02115 \\ bepartment of Chemical Engineering, Massachusetts Institute of Technology, 45 Carleton \\ Street, Cambridge, Massachusetts 02142 \\ 'Director of Biostatistics, Department of Anesthesiology, Childrens Hospital Boston, Harvard \\ Medical School, 300 Longwood Avenue, Boston 02115 \\ dDepartment of Cancer Immunology and AIDS, Dana-Farber Cancer Institute, 44 Binney Street, \\ JFB 824, Boston 02115 \\ eDepartment of Pathology, Division of AIDS, Harvard Medical School, Boston 02115 \\ 'Department of Pathology, Brigham and Women's Hospital, 75 Francis St., Boston MA 02115
}

\section{Abstract}

There are approximately 33.4 million adults living with HIV worldwide of which an estimated 15.7 million are women. Although there has been enormous progress in the therapy of HIV/AIDS, treatment is not curative. Prevention is therefore of paramount importance, but vaccine-based and microbicidal approaches are still in their infancy. Since women acquire the virus largely through sexual intercourse, we developed liposomal systems potentially suitable for intravaginal use to prevent HIV-1 infection. We formulated liposomes from a range of naturally-occurring and synthetic lipids with varying physicochemical properties, and tested their ability to inhibit infection of transformed cells that express receptors specific to the virus. We identified formulations with the most favorable balance between decreasing HIV infection and causing cytotoxicity (i.e. therapeutic index). The therapeutic index improved with increasing cardiolipin content, and degree of unsaturation. Tissue reaction to these formulations was benign after intravaginal instillation in an in vivo female mouse model. These results support the potential use of cardiolipin-based liposomes enriched with synthetic lipids as microbicides for the prevention of HIV infection in women.

\section{Keywords}

liposome; HIV; AIDS; prophylaxis; cardiolipin

(C) 2011 Elsevier Ltd. All rights reserved.

*Corresponding author: Laboratory for Biomaterials and Drug Delivery Department of Anesthesiology Division of Critical Care Medicine Children's Hospital, Harvard Medical School 300 Longwood Ave Boston, MA 02115 Phone: 617-355-7327, FAX: 617-730-0453, daniel.kohane@childrens.harvard.edu

Publisher's Disclaimer: This is a PDF file of an unedited manuscript that has been accepted for publication. As a service to our customers we are providing this early version of the manuscript. The manuscript will undergo copyediting, typesetting, and review of the resulting proof before it is published in its final citable form. Please note that during the production process errors may be discovered which could affect the content, and all legal disclaimers that apply to the journal pertain. 


\section{Introduction}

Statistics regarding the epidemic of HIV/AIDS across the globe are grim, and there has been little success in formulating a cure despite advances such as the development of nucleoside and non-nucleoside reverse transcriptase inhibitors, protease inhibitors, and inhibitors of HIV integrase and HIV entry [1]. Furthermore, the improvements in treatment that do exist are often difficult to disseminate outside of the developed world due to their high costs. In the developing world, less than a third of people have access to such treatments and new infections far outstrip the ability to treat everyone infected with the virus [2]. Moreover, current treatments are susceptible to the development of drug resistance, and have associated toxicities. Consequently, there has been strong interest in developing means of prevention. An example of a recent promising approach is the combinatorial vaccine that was able to cut the risk of infection by more than $31 \%$ in almost 16,000 participants [3]. Other studies have identified antibodies that prevent HIV infection in laboratory-based experiments [4]. Nonetheless, there remains an immediate and urgent need for low-cost, safe and effective means of preventing the spread of HIV, especially for women.

Topical microbicides present an important strategy for preventing HIV transmission through sexual intercourse, which is the predominant mode of HIV spread worldwide [5-7] .

Statistics suggest the incidence of HIV is increasing among women at alarming rates with half of the total number of infections in the developing world being in women [8]. Almost 61 percent of adults living with HIV in Sub-Saharan Africa alone are women [9] . Women are particularly vulnerable in that they are frequently not in control of their lives and/or choice of sexual partners. For these reasons, as well as epidemiological considerations, there is a need for female-controlled methods for prevention of HIV transmission by sexual intercourse. Several compounds e.g. tenofovir (reverse transcriptase inhibitor), griffithsin, cyanovirin-N (both virus entry inhibitors) and siRNAs, are at various stages of development for use as microbicides [10-12]. Despite this level of effort there is still no such product available on the market due to a variety of factors including lack of effectiveness or regulatory roadblocks $[7,13]$.

Here we have developed a range of liposomal formulations to inhibit HIV infection, from lipids with differing physicochemical properties, so as to provide antiviral effectiveness with reduced cytotoxicity, i.e. improved therapeutic indices. Liposomes - micro- or nanoparticulate lipid bilayer structures that resemble those of living cells - can bind to the HIV-1 virus if they have certain specific lipid compositions $[14,15]$ and can modulate HIV infectivity [16]. Such systems have been used to deliver anti-HIV drugs to infected cells [17]. Tissue reaction to the formulations was determined in vivo. Such systems would be appealing in that untargeted particles would be simpler to formulate and relatively cheap to produce, particularly compared to particles modified with expensive recombinant proteins. Such liposomal formulations could be introduced intravaginally prior to coitus and would be a potentially simple and economically viable system, especially for the developing world.

\section{Methods}

Materials

Ethanol and phosphate buffered saline (PBS) was purchased from Sigma (St. Louis, MO). Lipids: cardiolipin; from bovine heart as a sodium salt (CL), L- $\alpha$-Phosphatidylglycerol; soy (PG), L- $\alpha$-Phosphatidylinositol; from bovine liver as a sodium sat (PI), L- $\alpha-$

Phosphatidylserine; from porcine brain as a sodium salt (PS), L- $\alpha$-Phosphatidylcholine; soy (PC), 1,2-dioleoyl-3-trimethylammonium-propane; chloride salt (DOTAP), 1,2-dioleoyl-snglycero-3-phosphocholine (DOPC), 1,2-dimyristoyl-sn-glycero-3-phosphocholine (DMPC), 
1,2-dipalmitoyl-sn-glycero-3-phosphocholine (DPPC) and L- $\alpha$-phosphatidylcholine; soy hydrogenated (HSPC) all from Avanti Polar Lipids Inc. (Alabaster, AL).

\section{Liposome Preparation}

Multi-lamellar liposomes were prepared using the ethanol injection method [18] . In brief, stock lipids (Table 1) were dissolved in ethanol $5^{\circ} \mathrm{C}$ above their phase transition temperature at $100 \mathrm{mg} / \mathrm{mL}$ and pertinent volumes were injected into phosphate buffered saline at the same temperature as the ethanol solution. Ethanol (being less than 10vol\%) was removed by dialysis or by repeated centrifugation and supernatant removal. For most of our experiments $100 \mathrm{~mole} \%$ corresponds to a final lipid concentration of $2 \mathrm{mg} / \mathrm{mL}$.

\section{Liposomes Characterization}

Liposomes were sized using a Multisizer 3 Coulter Counter ${ }^{\circledR}$ (Beckmann Coulter, Brea, $\mathrm{CA}$ ). Zeta potential (surface charge in $\mathrm{mV}$ ) was measured by quasi-elastic laser light scattering with a ZetaPALS dynamic light scattering detector (Brookhaven Instruments) and ZetaPlus software.

\section{Cell viability assay}

Human vaginal epithelial cells, CRL-2616 ${ }^{\mathrm{TM}}$ (ATCC, Manassas, VA) were cultured in keratinocyte serum free medium (Invitrogen, Carlsbad, CA) as per the manufacturer's instructions. Cells were seeded at a uniform density on 96 well plates in $200 \mu \mathrm{l}$ medium. On the day of the experiment, medium was removed and liposomes $(0-0.6 \mathrm{mg} / \mathrm{mL})$ suspended in phosphate buffered saline added to the cells. After 48 hours the liposomal solution was replaced with fresh medium. In some wells WST-1 dye (Roche, Mannheim, Germany) was added and incubated at $37^{\circ} \mathrm{C}$ for 4 hours. The absorbance of the formazan dye produced was measured at $450 \mathrm{nM}$ using a SpectraMax 384 Plus fluorometer (Molecular Devices, Sunnyvale, CA). The principle of WST-1 dye is similar to the MTT dye however it does not require the solubilization step. Cells to which medium or PBS without any liposomes was added served as untreated controls.

\section{Infection assay}

All handling of viruses and virus infected cell lines were performed in accordance with the guidelines recommended by the Centers of Disease Control. 293T human embryonic kidney cells were co-transfected with plasmids expressing the pCMV $\Delta \mathrm{P} 1 \Delta$ env HIV Gag-Pol packaging construct, the R5 YU2 envelope glycoproteins, and the firefly luciferaseexpressing vector at a DNA ratio of 1:1:3 mg using the Effectene transfection reagent (Qiagen, Gaithersburg, MD). Co-transfection produced single-round, replication-defective viruses. The virus-containing supernatants were harvested 24-30 hours after transfection, filtered $(0.45 \mu \mathrm{m})$, aliquoted, and frozen at $-80^{\circ} \mathrm{C}$ until further use. The reverse transcriptase (RT) activities of all viruses were measured as described previously [19-21]. HeLa-CD4CCR5 (JC53) target cells were seeded at a density of $6 \times 10^{3}$ cells/well in 96-well luminometer-compatible tissue culture plates (Perkin Elmer, Waltham, MA) 24 hours before infection.

On the day of the infection, various liposomal formulations $(0-0.6 \mathrm{mg} / \mathrm{mL})$ were incubated with recombinant viruses $\left(10,000 \mathrm{RT}\right.$ units) at $37^{\circ} \mathrm{C}$ for 30 minutes. The mixtures were then added to the target cells for 2 hours at $37^{\circ} \mathrm{C}$; after this time, the medium was removed from each well, fresh medium was added and the cells were maintained for 48 hours at $37^{\circ} \mathrm{C}$. This is referred to as the virus-first approach in some parts of the text. 
In some cases the liposomes were added to cells for 2 hours at $37^{\circ} \mathrm{C}$ and then the viral stock was added and the entire process repeated as described representing 'cells pretreated with liposomes' condition. This is referred to as the cells-first approach in some parts of the text.

Following the incubation, medium was removed, cells were lysed by addition of passive lysis buffer (Promega, Madison, WI) and three freeze-thaw cycles. An EG\&G Berthold Microplate Luminometer LB 96V was used to measure the luciferase activity of each well after the addition of luciferin buffer and D-luciferin potassium salt (BD Biosciences Pharmingen, Franklin Lakes, VT). The luciferase activity is a measure of virus infection. The luciferase activity i.e. virus infectivity, without any liposomes is expressed as $100 \%$. The luciferase activity levels from the liposome treated conditions was normalized to the untreated levels and expressed as a percentage.

\section{Statistics}

Using the viral infectivity data expressed as a percentage we calculated the $\mathrm{IC}_{50}$ i.e. the mean concentration at which there is $50 \%$ inhibition of infection for each of the liposomal formulation tested thus called the inhibitory concentration 50 . Similarly using the cell viability data we calculated the $\mathrm{LD}_{50}$ i.e. the mean concentration or dose at which there is toxicity or death to $50 \%$ of the cell population for each of the liposomal formulation tested thus called the lethal dose 50. Subsequently we calculated the TI, therapeutic index as the ratio of the lethal dose 50 to the inhibitory concentration $50\left(\mathrm{LD}_{50} / \mathrm{IC}_{50}\right)$ for each of the liposomal formulations. The liposomal formulations with the top 3 therapeutic indices identified from the group were employed for testing biocompatibility in the in vivo model.

$\mathrm{IC}_{50}$ and $\mathrm{LD}_{50}$ were determined using probit analysis with concentration as the predictor of a binary response, with $95 \%$ upper and lower confidence intervals (CI) estimated for each compound using fiducial limits [22] . A mixed model analysis of variance (ANOVA) was applied to compare $\mathrm{IC}_{50}$ values between the virus-first and cells-first approaches. The Pearson correlation coefficient (r) was used to measure the linear association between physiological parameters such as the number of carbons and percentage of cardiolipin and performance of the formulations as defined by TI. Two-tailed values of $\mathrm{P}<0.05$ were considered statistically significant. Analysis of the data was performed using SPSS version 18.0 (SPSS Inc./IBM, Chicago, IL).

\section{In vivo intravaginal instillation of liposomes}

All the animals were cared for in compliance with protocols approved by the Animal Care and Use Committee at the Massachusetts Institute of Technology and the Principles of Laboratory Animal Care (NIH publication \#85-23, revised 1985).

Swiss Webster mouse model was used to evaluate the toxicity and inflammation associated with the liposomal application. Six-10 week old female Swiss Webster mice were hormonally synchronized 7 days prior to the start of each experiment with a subcutaneous injection of Depo-Provera (Pharmacia and Upjohn Company, Peapack, N.J) diluted in lactated ringers saline solution to a final concentration of $3 \mathrm{mg}$ per mouse [23]. Following synchronization, the mouse was anesthetized using 2-3\% isoflurane in 100\% oxygen and received a single intravaginal inoculation $(50 \mu \mathrm{l})$ using Tom Cat catheters (Kendall Sovereign ${ }^{\mathrm{TM}}$, Mansfield, MA) of the test compound. Mice treated with diluent (PBS) served as control. Mice were sacrificed 3 and 7 days post injection. The entire reproductive tract was surgically excised. Tissues were formalin fixed, embedded in paraffin, sectioned, and stained with hematoxylin and eosin examination using standard histological techniques. Three liposomal formulations $\left(\mathrm{CL}_{40} \mathrm{DMPC}_{60}, \mathrm{CL}_{100}, \mathrm{CL}_{60} \mathrm{DPPC}_{40}\right)$ were tested at total 
lipid concentration of 2,10 and $20 \mathrm{mg} / \mathrm{mL}$ with four animals in each group along with untreated and PBS treated animals.

\section{Live animal Imaging}

For this study $\mathrm{CL}_{40} \mathrm{DMPC}_{60}$ liposomes $(20 \mathrm{mg} / \mathrm{mL})$ were formulated using ethanol injection into PBS solution maintained at $40^{\circ} \mathrm{C}$. The PBS solution contained non-reactive DyLight 649 free acid dye (ThermoFisher, Rockford, IL) that has an excitation of $682 \mathrm{~nm}$ and emission of $712 \mathrm{~nm}$. This dye was selected since it has wavelengths of above $600 \mathrm{~nm}$ as at wavelengths below $600 \mathrm{~nm}$ autofluorescence signal from the tissue during imaging increases significantly. Dye encapsulating liposomes were dialyzed against PBS using 100,000 MW cut-off membranes (Spectra/Por, Rancho Dominguez, CA) for 24 hours at $4^{\circ} \mathrm{C}$.

In vivo fluorescence imaging was performed with an IVIS spectrum measurement system (Xenogen, Hopkinton, MA). The animals were maintained under inhaled anesthesia using (2-3\%) isoflurane in $100 \%$ oxygen at a flow rate of $2.5 \mathrm{~L} / \mathrm{min}$. A halogen lamp with a dichroic reflector provides light for fluorescence excitation. Living Image software controls illumination intensity and selection of excitation filter wheel. A secondary lens focuses the light into the imaging chamber where the emission filter wheel collects the fluorescent emission and focuses it on the charged couple device (CCD) camera. The CCD camera measures the amount of incident photons. Binning, which controls the pixel size on the camera, was set to $8 \times 8$ and field of view of $12.8 \mathrm{~cm}$ was used for imaging. Exposure time and relative size of the aperture opening were optimized for the acquired image. Data were acquired and analyzed using manufacturers proprietary Living Image 3.1 software. All the images are presented in radiant efficiency defined as fluorescence emission radiance per incident excitation power. The 'region of interest' (ROI) tool was used to measure the signal intensity at the site of intra-vaginal injection. Images were obtained 1, 6, 24 and 48 hours post injection.

Living Image software was employed to generate a reconstruction of the animal surface derived from the structured light images. Fluorescent Tomography (FLIT) was used to analyze the light emission to generate a 3D reconstruction of fluorescent light source inside the animal. The reconstruction is generated from transillumination images using appropriate excitation and emission filters from 8-10 locations that form a rectangle around the source. The 'center of mass' tool measures the total fluorescent yield inside the animal and identifies most appropriate organ where the fluorescence source is located based on a reference organ atlas fit to the animal.

\section{Results}

\section{Liposomal Formulations}

Multilamellar liposomes approximately $3 \mu \mathrm{m}$ in diameter were formulated from one or more lipids that varied in physicochemical characteristics (Tables 1A, B). Cardiolipin was selected because of prior reports that liposomal cardiolipin inhibited HIV infection in vitro [16]. Synthetic derivatives of phosphatidylcholine were used in some formulations.

\section{Evaluation of viral infection and cytotoxicity of the liposomal formulations}

Liposomes were incubated with YU2, a CCR5 using HIV-1 isolate, prior to the mixture being added to HeLa JC53 cells (the virus-first approach). The concentration at which there was $50 \%$ inhibition of infection of those cells $\left(\mathrm{IC}_{50}\right)$, was calculated for each formulation by probit analysis (see Statistics section). Separately, the concentration at which 50\% of human vaginal epithelial cells died when exposed to each liposomal formulation $\left(\mathrm{LD}_{50}\right)$ was calculated, for each formulation. The therapeutic index for each formulation was calculated 
from these $\left(\mathrm{TI}=\mathrm{LD}_{50} / \mathrm{IC}_{50}\right)$. A greater therapeutic index signifies improved safety for a given effect. Results for all formulations tested are in Supplemental Tables 1A-C, and are summarized in Fig. 1.

Of a first set of liposomes comprising single naturally occurring negatively-charged lipids (CL, PI, PG. PS; Table 1A), cardiolipin had the highest therapeutic index, by a factor of almost four (Supplemental Table 1C, Fig. 1). Despite that favorable therapeutic index, cardiolipin itself was relatively toxic (Supplemental Table 1B). To improve the therapeutic index of the cardiolipin liposomes, synthetic lipids (DOPC, DMPC, DPPC, HSPC) were coincorporated that produced no toxicity when formulated as single-lipid liposomes (Supplemental Table 1B). In general, addition of the second lipids raised the $\mathrm{IC}_{50}$ and the $\mathrm{LD}_{50}$ (i.e. the liposomes became less effective but less toxic), with varying effects on the therapeutic index (Supplemental Table 1C). We could not calculate the therapeutic indices for some liposomes because they were ineffective in preventing viral infection $\left(\mathrm{DOPC}_{100}\right)$, and/or because there was no toxicity $\left(\mathrm{CL}_{30} \mathrm{DOPC}_{70}, \mathrm{DMPC}_{100}, \mathrm{CL}_{30} \mathrm{DPPC}_{70}\right.$, $\mathrm{CL}_{30} \mathrm{HSPC}_{70}$ ). Despite their low toxicity, the latter formulations were not pursued because their $\mathrm{IC}_{50}$ s were relatively high (i.e. they were ineffective). Of all the formulations tested, the three with the highest therapeutic indices were $\mathrm{CL}_{40} \mathrm{DMPC}_{60}(\mathrm{TI}=7.6), \mathrm{CL}_{100}(\mathrm{TI}=6)$ and $\mathrm{CL}_{60} \mathrm{DPPC}_{40}(\mathrm{TI}=4.6)($ Table 2$)$.

When all formulations were considered together in correlating the physicochemical parameters (Table 1) with biological performance (Fig. 1), it was found that the therapeutic index correlated positively with lipids having a greater number of carbons $(\mathrm{r}=0.58, \mathrm{P}=$ $0.02)$, a greater number of unsaturated bonds $(\mathrm{r}=0.55, \mathrm{P}=0.03)$, and a higher percentage of cardiolipin $(\mathrm{r}=0.64, \mathrm{P}<0.01)$. Although the $\mathrm{IC}_{50}$ and $\mathrm{LD}_{50}$ themselves did not correlate with any physicochemical properties, the following qualitative observation of trends could be made. Among formulations containing cardiolipin, there was a trend toward a lower $\mathrm{IC}_{50}$ with increasing cardiolipin content. For example the $\mathrm{IC}_{50}$ for $\mathrm{CL}_{100}<\mathrm{CL}_{60} \mathrm{HSPC}_{40}<$ $\mathrm{CL}_{40} \mathrm{HSPC}_{60}$. This relationship did not hold for $\mathrm{CL}_{60} \mathrm{DMPC}_{40}$. Also, the $\mathrm{LD}_{50}$ tended to increase with a decreasing number of carbons in the acyl chains of the second (non-CL) lipid. For example, the $\mathrm{LD}_{50}$ for $\mathrm{CL}_{40} \mathrm{HSPC}_{60}<\mathrm{CL}_{40} \mathrm{DPPC}_{60}<\mathrm{CL}_{40} \mathrm{DMPC}_{60}$. Here again, our results for $\mathrm{CL}_{60} \mathrm{DMPC}_{40}$ did not fit the trend.

The ability of the three best liposome formulations to inhibit infection when applied prior to exposure to virus (i.e. as would be used ideally by humans) was determined by pretreating cells with liposomes for 2 hours prior to inoculation with virus (the cells-first approach; Table 3). For $\mathrm{CL}_{40} \mathrm{DMPC}_{60}$ and $\mathrm{CL}_{100}$ the $\mathrm{IC}_{50} \mathrm{~s}$ was similar to that generated by the virusfirst method. The $\mathrm{IC}_{50}$ of $\mathrm{CL}_{60} \mathrm{DPPC}_{40}$ was numerically higher with the cells-first method. However, the difference between the cell-first and virus-first methods was not statistically significant for any of the formulations (all P> 0.10), implying that these liposomal formulations would also be effective if used prior to exposure to virus, as with a vaginal microbicide.

\section{Live animal imaging}

Hormonally synchronized female mice received a single intravaginal instillation of $\mathrm{CL}_{40} \mathrm{DMPC}_{60}$ encapsulating a fluorescent dye solution. The mice were imaged at $1,6,24$, and 48 hours post instillation (Fig. 2). Radiant efficiency decreased over time suggesting elimination and/or degradation of the liposomes. The anatomical location of the source of the fluorescence signal was identified by fluorescent tomographic (FLIT) reconstruction as described in Methods (Supplemental Figure 1A), which confirmed that the dyeencapsulating liposomes were in the vaginal region (Supplemental Figure 1B). These results suggested that the liposomes either stayed within the vaginal vault or left the body, and that significant quantities did not leach to other compartments, e.g. into the peritoneum. 


\section{Evaluation of the biocompatibility of liposomes in vivo}

Liposomal formulations were introduced intravaginally in female mice at 2, 10 and $20 \mathrm{mg} /$ $\mathrm{mL}$. Animals were euthanized at 3 and 7 days post-instillation. Tissues were processed into hematoxylin and eosin stained sections using standard histological techniques. There were no differences in the vaginal epithelium and surrounding regions between animals treated with $\mathrm{CL}_{40} \mathrm{DMPC}_{60}$ liposomes (Fig. 3) and those treated with $\mathrm{CL}_{100}$ or $\mathrm{CL}_{60} \mathrm{DPPC}_{40}$ formulations, or phosphate-buffered saline (Supplemental Figure 2). In other words, the epithelia and surrounding regions appeared normal at all time points and concentrations, and were indistinguishable from animals treated with an equal volume of PBS alone.

\section{Discussion}

At the end of 2009 the largest clinical trial conducted to date for a preventive HIV gel, PRO 2000, by the Microbicides development program (MDP) found no evidence of reducing HIV infection in women despite initial promising results in a smaller study [24]. Nonetheless, there are some encouraging developments: the recent Center for AIDS Program for Research in South Africa (CAPRISA) study of tenofovir gel showed a 39\% reduction in new HIV [25]; large clinical trials are being planned. As noted in the Introduction, there is considerable interest in developing microbicidal approaches to preventing HIV infection. In addition, various gold, silver, dendrimer and fullerene-based nanotechnologies are being developed as nano-microbicides $[9,26]$. These studies highlight the urgent need to develop safe and effective intravaginal microbicides to prevent HIV infection.

To address this need we developed liposomal formulations, with the intention that they would be effective and inexpensive, and could be easily placed in the vagina prior to coitus. Liposomes were selected because of the extensive literature on their formulation and use, and the fact that they are used clinically, including in vaginal applications [27]. We selected large multilamellar liposomes as they are simple to formulate into ointments and are stable for long periods of time [18] .

This study was designed as a broad screen of formulations for effectiveness in preventing HIV infection, and a subsequent optimization to minimize toxicity, not as a mechanistic study of the effects of physicochemical properties on outcome. Nonetheless, we were able to detect statistically significant correlations between cardiolipin content, the number of carbons per phospholipid, and the number of unsaturated bonds. With the caveats noted in the results, there also were potential trends relating increasing cardiolipin content with a lower $\mathrm{IC}_{50}$, and a decreasing number of carbons with a higher $\mathrm{LD}_{50}$.

Our finding that many of the formulations developed were capable of inhibiting HIV infections was consistent with the reports that the lipid composition of liposomal membranes can affect the rate and extent of HIV-1 fusion [14], and the infectivity of HIV-1 in cell culture [16]. Our study extends the latter observation to a broad range of formulations and addresses the important practical issue - for eventual clinical use - of optimizing the therapeutic index by minimizing cytotoxicity. Our finding that the proportion of cardiolipin bore a relation to therapeutic index was consistent with the same finding for HIV-1 fusion with membranes [14]. Despite that, and while cardiolipin did have the lowest $\mathrm{IC}_{50}$, it did not have the highest therapeutic index (Table 2) - which was had by $\mathrm{CL}_{40} \mathrm{DMPC}_{60}$, which combined cardiolipin with a synthetic phospholipid.

Tissue reaction to these formulations was benign; in particular, there was no or minimal inflammatory response. Inflammation might have impaired mucosal integrity, which could increase the risk of infection. 


\section{Conclusions}

Cardiolipin-containing liposomes were optimized with respect to therapeutic index (cytotoxicity vs. effectiveness in inhibiting HIV-1 infection in vitro), and had benign tissue reaction in vivo. The $\mathrm{CL}_{40} \mathrm{DMPC}_{60}$ liposomes had the best therapeutic index $(\mathrm{TI}=7.56)$. Systems such as these could be inexpensive and easy to develop, and could be of particular usefulness in the developing world where resources are limited.

\section{Supplementary Material}

Refer to Web version on PubMed Central for supplementary material.

\section{Acknowledgments}

This work is supported by the Grand Challenges in Global Health GCE - Phase I grant (to R.L., D.S.K and N. Malavia), and NIH GM073626 (D.S.K). A.S. thanks the Misrock Foundation for a postdoctoral fellowship. N. Madani was supported by an American Foundation for AIDS Research Mathilde Krim Fellowship in Basic Biomedical Research \# 107431-45-RFRL. JC53 cells were the generous gift of Dr. David Kabat at Oregon Health Sciences University.

\section{References-Liposomes for HIV prophylaxis}

1. Fauci AS. 25 years of HIV. Nature. 2008; 453(7193):289-290. [PubMed: 18480799]

2. Fauci AS. Pathogenesis of HIV disease: opportunities for new prevention interventions. Clin Infect Dis. 2007; 45(Suppl 4):S206-212. [PubMed: 18190288]

3. Berkhout B, Paxton WA. HIV vaccine: it may take two to tango, but no party time yet. Retrovirology. 2009; 6:88. [PubMed: 19818121]

4. Burton DR, Weiss RA. AIDS/HIV. A boost for HIV vaccine design. Science. 2010; 329(5993):770773. [PubMed: 20705840]

5. Grant RM, Hamer D, Hope T, Johnston R, Lange J, Lederman MM, et al. Whither or wither microbicides? Science. 2008; 321(5888):532-534. [PubMed: 18653884]

6. Hendrix CW, Cao YJ, Fuchs EJ. Topical microbicides to prevent HIV: clinical drug development challenges. Annu Rev Pharmacol Toxicol. 2009; 49:349-375. [PubMed: 19006450]

7. Klasse PJ, Shattock RJ, Moore JP. Which topical microbicides for blocking HIV-1 transmission will work in the real world? PLoS Med. 2006; 3(9):e351. [PubMed: 16903780]

8. Pope M, Haase AT. Transmission, acute HIV-1 infection and the quest for strategies to prevent infection. Nat Med. 2003; 9(7):847-852. [PubMed: 12835704]

9. Buckheit RW Jr. Watson KM, Morrow KM, Ham AS. Development of topical microbicides to prevent the sexual transmission of HIV. Antiviral Res. 2010; 85(1):142-158. [PubMed: 19874851]

10. Li Q, Estes JD, Schlievert PM, Duan L, Brosnahan AJ, Southern PJ, et al. Glycerol monolaurate prevents mucosal SIV transmission. Nature. 2009; 458(7241):1034-1038. [PubMed: 19262509]

11. O'Keefe BR, Vojdani F, Buffa V, Shattock RJ, Montefiori DC, Bakke J, et al. Scaleable manufacture of HIV-1 entry inhibitor griffithsin and validation of its safety and efficacy as a topical microbicide component. Proc Natl Acad Sci U S A. 2009; 106(15):6099-6104. [PubMed: 19332801]

12. Woodrow KA, Cu Y, Booth CJ, Saucier-Sawyer JK, Wood MJ, Saltzman WM. Intravaginal gene silencing using biodegradable polymer nanoparticles densely loaded with small-interfering RNA. Nat Mater. 2009; 8(6):526-533. [PubMed: 19404239]

13. McGowan I. Microbicides for HIV prevention: reality or hope? Curr Opin Infect Dis. 2010; 23(1): 26-31. [PubMed: 19935418]

14. Larsen CE, Nir S, Alford DR, Jennings M, Lee KD, Duzgunes N. Human immunodeficiency virus type 1 (HIV-1) fusion with model membranes: kinetic analysis and the role of lipid composition, pH and divalent cations. Biochim Biophys Acta. 1993; 1147(2):223-236. [PubMed: 8476916] 
15. Raulin J. Human immunodeficiency virus and host cell lipids. Interesting pathways in research for a new HIV therapy. Progress in lipid research. 2002; 41(1):27-65. [PubMed: 11694268]

16. Konopka K, Davis BR, Larsen CE, Alford DR, Debs RJ, Duzgunes N. Liposomes modulate human immunodeficiency virus infectivity. J Gen Virol. 1990; 71(Pt 12):2899-2907. [PubMed: 2273389]

17. Torchilin VP. Recent advances with liposomes as pharmaceutical carriers. Nat Rev Drug Discov. 2005; 4(2):145-160. [PubMed: 15688077]

18. Sivan S, Schroeder A, Verberne G, Merkher Y, Diminsky D, Priev A, et al. Liposomes act as effective biolubricants for friction reduction in human synovial joints. Langmuir. 2010; 26(2): 1107-1116. [PubMed: 20014818]

19. Madani N, Perdigoto AL, Srinivasan K, Cox JM, Chruma JJ, LaLonde J, et al. Localized changes in the gp120 envelope glycoprotein confer resistance to human immunodeficiency virus entry inhibitors BMS-806 and \#155. J Virol. 2004; 78(7):3742-3752. [PubMed: 15016894]

20. Madani N, Schon A, Princiotto AM, Lalonde JM, Courter JR, Soeta T, et al. Small-molecule CD4 mimics interact with a highly conserved pocket on HIV-1 gp120. Structure. 2008; 16(11):16891701. [PubMed: 19000821]

21. Schon A, Madani N, Klein JC, Hubicki A, Ng D, Yang X, et al. Thermodynamics of binding of a low-molecular-weight CD4 mimetic to HIV-1 gp120. Biochemistry. 2006; 45(36):10973-10980. [PubMed: 16953583]

22. Finney, DJ. Probit analysis. 3d ed. Cambridge University Press; New York: 1971.

23. Catalone BJ, Kish-Catalone TM, Budgeon LR, Neely EB, Ferguson M, Krebs FC, et al. Mouse model of cervicovaginal toxicity and inflammation for preclinical evaluation of topical vaginal microbicides. Antimicrob Agents Chemother. 2004; 48(5):1837-1847. [PubMed: 15105142]

24. Microbicides, GC. Announcing the results of PRO 2000. 2009. available from: http://www.global-campaign.org/

25. Center for the AIDS Programme of Research in South Africa (CAPRISA). Study of microbicide gel shows reduced risk of HIV \& Herpes infections in women. XVIII International AIDS conference; Viennna, Austria. 2010.

26. Ndesendo VM, Pillay V, Choonara YE, Buchmann E, Bayever DN, Meyer LC. A review of current intravaginal drug delivery approaches employed for the prophylaxis of HIV/AIDS and prevention of sexually transmitted infections. AAPS PharmSciTech. 2008; 9(2):505-520. [PubMed: 18431651]

27. du Toit LC, Pillay V, Choonara YE. Nano-microbicides: challenges in drug delivery, patient ethics and intellectual property in the war against HIV/AIDS. Adv Drug Deliv Rev. 2010; 62(4-5):532546. [PubMed: 19922751] 


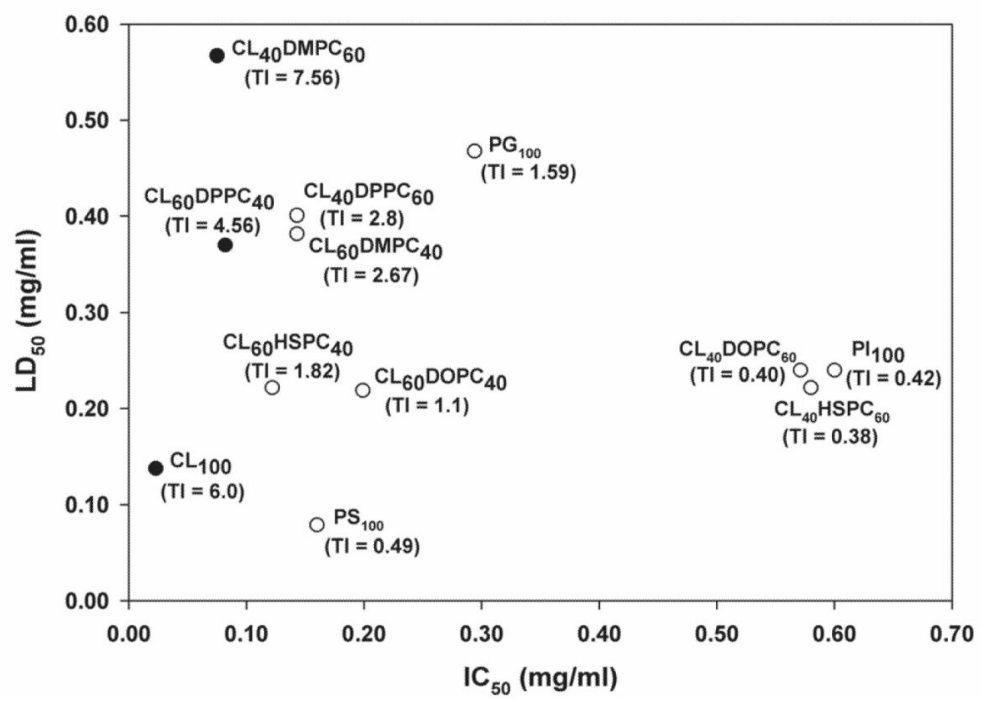

Figure 1.

$\mathrm{IC}_{50}$ and $\mathrm{LD}_{50}$ values with corresponding therapeutic indices (TI) in parentheses for the various liposomes. Filled circles denote the three formulations with the highest TIs. 
A)

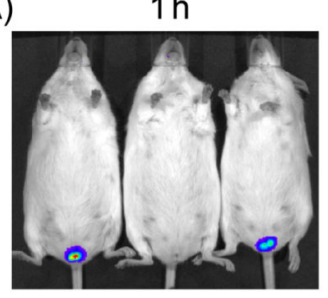

$24 \mathrm{~h}$

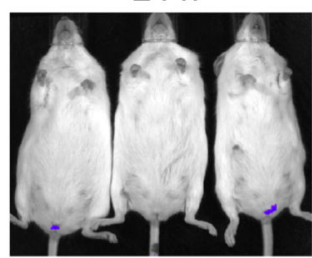

B)

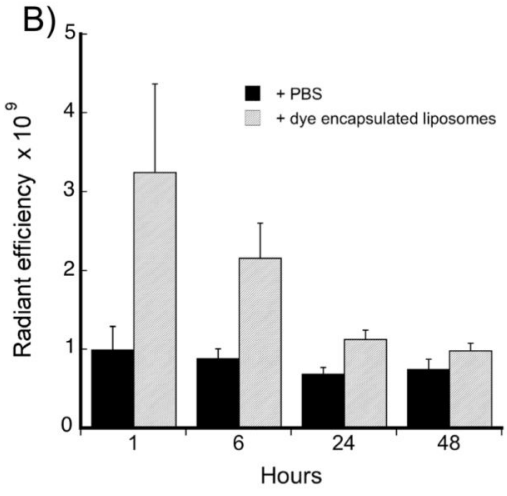

$6 \mathrm{~h}$

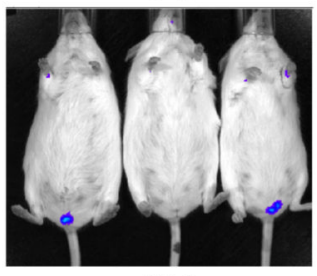

$48 \mathrm{~h}$

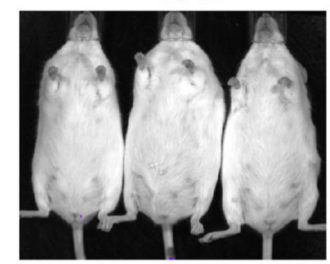

$$
\text { . }
$$

liposomes encapsulating Dylight $649(20 \mathrm{mg} / \mathrm{mL})$ or PBS (middle animal in each image) at various time points. B. Quantification of radiant efficiency at each time point around the region of interest. Data are means \pm SD with $n=8$ in each group 

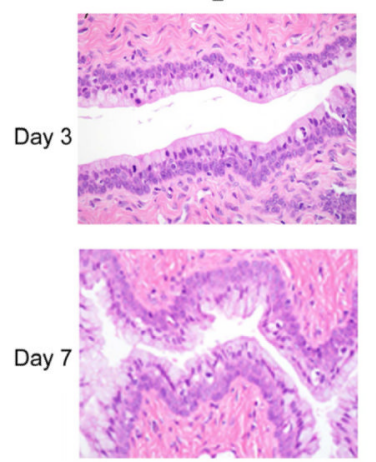

Concentration $\mathrm{mg} / \mathrm{mL}$

10
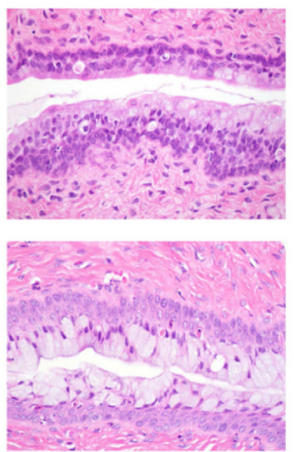

20
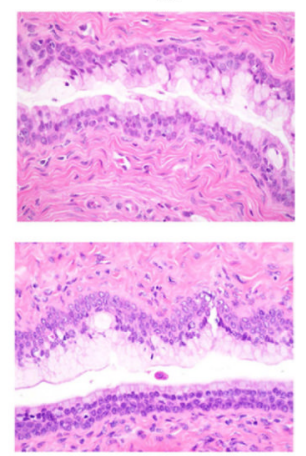

Figure 3.

Photomicrographs of hematoxylin-eosin stained sections of the murine vaginal mucosa 3 and 7 days after instillation of $\mathrm{CL}_{40} \mathrm{DMPC}_{60}$ liposomes at three concentrations. Data for $\mathrm{CL}_{100}, \mathrm{CL}_{60} \mathrm{DPPC}_{40}$, and PBS are in the supplement. 
Table 1A

Charge and tail length of lipids used to formulate liposomes

\begin{tabular}{|c|c|}
\hline Name of lipid & Net Charge $\boldsymbol{a}$ \\
\hline Cardiolipin (CL) & -2 \\
\hline L- $\alpha$-phosphatidylglycerol (PG) & -1 \\
\hline L- $\alpha$-Phosphatidylinositol (PI) & -1 \\
\hline L- $\alpha$-Phosphatidylserine (PS) & -1 \\
\hline $\begin{array}{c}\text { 1,2-dioleoyl-sn-glycero-3- } \\
\text { phosphocholine (DOPC) }\end{array}$ & 0 \\
\hline $\begin{array}{c}\text { 1,2-dimyristoyl-sn-glycero-3- } \\
\text { phosphocholine (DMPC) }\end{array}$ & 0 \\
\hline $\begin{array}{c}\text { 1,2-dipalmitoyl-sn-glycero-3- } \\
\text { phosphocholine (DPPC) }\end{array}$ & 0 \\
\hline $\begin{array}{c}\text { L- } \alpha \text {-phosphatidylcholine, Soy } \\
\text { hydrogenated (HSPC) }\end{array}$ & 0 \\
\hline
\end{tabular}

${ }^{a}$ Derived from the total number of positive and negative charges on the molecular structure 
Table 1B

Composition and characterization of liposomes

\begin{tabular}{|c|c|c|c|c|}
\hline $\begin{array}{c}\text { Name of } \\
\text { formulation } \boldsymbol{a}\end{array}$ & $\begin{array}{c}\text { Zeta Potential } \\
(\mathbf{m V}) \boldsymbol{b}\end{array}$ & \# of carbons $\boldsymbol{c}$ & $\begin{array}{c}\text { \# of } \\
\text { unsaturated } \\
\text { bonds } \boldsymbol{d}\end{array}$ & $\begin{array}{c}\text { Unsaturation } \\
(\boldsymbol{\%})\end{array}$ \\
\hline $\mathrm{CL}_{100}$ & $-131.02 \pm 0.36$ & 72 & 8 & 11.1 \\
\hline $\mathrm{PG}_{100}$ & $-77.34 \pm 3.03$ & 34 & 1 & 2.9 \\
\hline $\mathrm{PI}_{100}$ & $-113.72 \pm 1.37$ & 38 & 3 & 7.9 \\
\hline $\mathrm{PS}_{100}$ & $-143.36 \pm 2.8$ & 36 & 1 & 2.8 \\
\hline $\mathrm{CL}_{60} \mathrm{DOPC}_{40}$ & $-96.18 \pm 4.03$ & 57.6 & 5.6 & 9.7 \\
\hline $\mathrm{CL}_{40} \mathrm{DOPC}_{60}$ & $-92.7 \pm 2.99$ & 50.4 & 4.4 & 8.7 \\
\hline $\mathrm{CL}_{30} \mathrm{DOPC}_{70}$ & $-61.43 \pm 6.59$ & 46.8 & 3.8 & 8.1 \\
\hline $\mathrm{DOPC}_{100}$ & $-9.65 \pm 0.065$ & 36 & 2 & 5.6 \\
\hline $\mathrm{CL}_{60} \mathrm{DMPC}_{40}$ & $-104.24 \pm 4.48$ & 54.4 & 4.8 & 8.8 \\
\hline $\mathrm{CL}_{40} \mathrm{DMPC}_{60}$ & $-99.51 \pm 2.94$ & 45.6 & 3.2 & 7.0 \\
\hline $\mathrm{CL}_{30} \mathrm{DMPC}_{70}$ & $-86.78 \pm 2.35$ & 41.2 & 2.4 & 5.8 \\
\hline $\mathrm{DMPCC}_{100}$ & $-0.083 \pm 1.83$ & 28 & 0 & 0.0 \\
\hline $\mathrm{CL}_{60} \mathrm{DPPC}_{40}$ & $-109.17 \pm 4.33$ & 56 & 4.8 & 8.6 \\
\hline $\mathrm{CL}_{40} \mathrm{DPPC}_{60}$ & $-99.3 \pm 1.43$ & 48 & 3.2 & 6.7 \\
\hline $\mathrm{CL}_{30} \mathrm{DPPC}_{70}$ & $-88 \pm 1.16$ & 44 & 2.4 & 5.5 \\
\hline $\mathrm{DPPC}_{100}$ & $-4.37 \pm 0.51$ & 32 & 0 & 0.0 \\
\hline $\mathrm{CL}_{60} \mathrm{HSPC}_{40}$ & $-128.9 \pm 3.09$ & 57.6 & 4.8 & 8.3 \\
\hline $\mathrm{CL}_{40} \mathrm{HSPC}_{60}$ & $-75.5 \pm 95$ & 50.4 & 3.2 & 6.3 \\
\hline $\mathrm{CL}_{30} \mathrm{HSPC}_{70}$ & $-67.32 \pm 2.24$ & 46.8 & 2.4 & 5.1 \\
\hline $\mathrm{HSPC}_{100}$ & $0.622 \pm 1.38$ & 36 & 0 & 0.0 \\
\hline
\end{tabular}

${ }^{a}$ Subscript denotes the mole $\% ; 100$ mole $\%=2 \mathrm{mg} / \mathrm{mL}$

${ }^{b}$ Determined as per Methods. Data are means $\pm \mathrm{SD}, \mathrm{n}=4$

${ }^{c}$ The number of carbons in the alkyl side chains. From website of provider (see Materials and Methods). If more than one lipid, the number of carbons is the average number of carbons weighted by the proportion of the lipids in the liposomes.

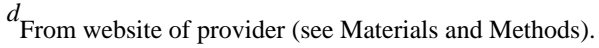

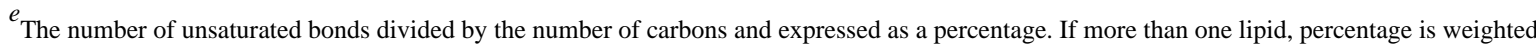
by the proportion of the lipids in the liposomes. 
Table 2

Three formulations with the highest TI and their corresponding $\mathrm{IC}_{50}$ and $\mathrm{LD}_{50}: \mathrm{CL}_{40} \mathrm{DMPC}_{60}, \mathrm{CL}_{100}$ and $\mathrm{CL}_{60} \mathrm{DPPC}_{40}$.

\begin{tabular}{|c|c|c|c|}
\hline $\begin{array}{c}\text { Name of } \\
\text { Formulation }\end{array}$ & $\mathbf{I C}_{\mathbf{5 0}}(\mathbf{m g} / \mathbf{m L})$ & $\mathbf{L D}_{\mathbf{5 0}}(\mathbf{m g} / \mathbf{m L})$ & $\begin{array}{c}\text { Therapeutic } \\
\text { Index TI }\left(\mathbf{L D}_{\mathbf{5 0}} /\right. \\
\left.\mathbf{I C}_{\mathbf{5 0}}\right)\end{array}$ \\
\hline $\mathrm{CL}_{40} \mathrm{DMPC}_{60}$ & 0.075 & 0.567 & 7.56 \\
\hline $\mathrm{CL}_{100}$ & 0.023 & 0.138 & 6.00 \\
\hline $\mathrm{CL}_{60} \mathrm{DPPC}_{40}$ & 0.082 & 0.374 & 4.56 \\
\hline
\end{tabular}


Table 3

$\mathrm{IC}_{50}$ of single and dual lipid liposomes

\begin{tabular}{|c|c|c|c|}
\hline \multicolumn{4}{|c|}{$\mathrm{IC}_{50}$ values $(95 \% \mathrm{CI})($ concentrations in $\mathrm{mg} / \mathrm{mL})$} \\
\hline & $\mathrm{CL}_{40} \mathrm{DMPC}_{60}$ & $\mathrm{CL}_{100}$ & $\mathrm{CL}_{60} \mathrm{DPPC}_{40}$ \\
\hline \multicolumn{4}{|l|}{ Method } \\
\hline Virus first & $0.083(0.024-0.175)$ & $0.023(0-0.067)$ & $0.001(0-0.077)$ \\
\hline Cells first & $0.067(0.003-0.147)$ & $0.025(0-0.068)$ & $0.091(0-0.271)$ \\
\hline P-value & 0.75 & 0.99 & 0.29 \\
\hline
\end{tabular}

IC 50s were calculated by two methods. i) Virus first: virus and liposomes incubated together then added to cells. ii) Cells first: cells incubated with liposomes followed by addition of viral stock. Data are means with $95 \%$ confidence intervals, obtained from $n=4$. Both methods were comparably effective with no significant differences for any of the three formulations. 